\title{
CATEGORISING RESOURCES OF HISTORICAL MEMORY IN RESEARCHING PUBLICISTIC TEXT Anastasiya Konyk ${ }^{7}$
}

\begin{abstract}
The article focuses on the allocation and analysis of the main resources of historical memory which are considered as peculiar indicators for studying publicist content and conceptual reading of discourses of historical memory in contemporary publications. It is relevant insofar as researching the use and intensification of these or other resources of historical memory allows us to observe changes in world landmarks, socio-political moods, ideological references and temperament and the dynamics of re-interpretation of historical facts and events by authors.
\end{abstract}

Key words: resources of historical memory, publicist text, literary-artistic and socio-political periodicals, interpretation of the past, method.

Research into the influence of opinion-making publicism on the formation, interpretation and transformation of historical memory is insufficiently developed and scantly integrated in the research of social communication in Ukraine although the concept of historical memory has entered public discourse long ago, and has become an object of scientific research as a repercussion of mass information itself. Authors of publications dealing with the historical memory are predominantly journalists, publicists and writers, since this theme stretches the boundaries of information research.

A considerable amount of theoretical and empirical material, characterizing the role of historical memory in the past and present socio-political life of the nations of Central and Western Europe, abounds within Western Cultural Studies.

The article aims at highlighting and describing resources of historical memory, which are interpreted as distinct indicators for the conceptual reading of publicist discourse on historical memory.

The practical value of the article may be measured in terms of the research results and conclusions which may be used by political analysts and journalists for the prognosis and development of media strategy. In practice, respective ideologies and global and cultural constructs formulated by publicists are deployed by mass media and propaganda organs to devise information strategy. This in turn constructs, within collective conscience, stereotypical historical regularity, historical analogies and reasoned-consequential connections to substantiate the internal and external politics of nations. 
For the theoretical basis of the research the concept of 'collective memory' by Halbwachs has been adopted [2005], which originated in the field of sociology, the theory of mentality, semiotics, the theory of communications and other humanities. Historian P. Nora [1999], philosopher T. Adorno [2005], the literary critic P. Hutton [2003], researchers in the sphere of media communications B. Zelizer [2014], A. Erll [2008] and K.Malicki [2012], have examined the complex set of problems, involving the study of memory and the broad spectrum of its interpretation, and considered the complexities of historical text, its authors and the means of interpretation.

Western European humanitarianism examines the paradigm of historical memory in today's information society in close correlation with the development of communication technologies. The impact of mass media is often perceived negatively, particularly when considering the forging of a 'memory industry', and the remodelling of the past and its symbolism into media product. Mass media transforms historical memory into a surfeit of information, created exclusively for the purposes of commercial benefit in order to meet recreational and consumer interests and to create opportunities for manipulation, demoralization, alienation and deconstruction of historical memory itself.

In terms of the transformation of society, when collective representation determined historical and civilizational choice, the role of opinion shaping publicism in actualising topics of society's historical memory is of particular importance. Broad public debate as presented in the literary-artistic and socio-political journals on the territory of the former Soviet Union from the end of 80-ies of the twentieth century provoked the so-called reading boom, when millions of copies of magazines and weekly publications appeared in the streets. The pages of journals primarily disseminated previously forbidden topics, a kind of 'inventory of the past', under emotional slogans calling for the revival of the historical memory of the people and the restoration of historical justice. A reassessment, 'de-mythicising' exalted Soviet era heroes, re-interpreting the official Soviet version of the past, reviewing historical patterns, historical analogies and causation have been characteristic features of intelligent reflections of the cultural and political elite. In this context, it is appropriate to quote Taras Lylo, a representative of the Lviv School of journalism, according to whom, for publicism history is a sphere of 'axiological experiences', on the basis of which 'empirically accessible bases for the identification of evil are produced'. From a position of national truth publicists aggrandise a pantheon of national heroes, hallmark categories of glory and filter arguments in retrospect to outline social perspective [Lylo, 2011].

Publicism has always been at the forefront in the social and political transformation of a nation. On the one hand, it substantiates a new civilizational choice providing moral and ethical coordinates to society, on the other - it reflects the current reality. In developing the concept of global publicism, as introduced by M. Shlemkevych in the first half of the twentieth century, Prof Y. Los' of the Lviv School of Journalism proposed the following definition of Publicism - "The verbal and visual areas of simulation of consciousness, manifestation of the dynamism of the human spirit, political and moral-philosophical development of history and current social practice, an all-encompassing implement for the shaping of individuality, the standard used to specify values and interests of individuals, social groups and Nations, and the embodiment of their cultural identity" [Los', 2004].

Therefore it may be suggested, that the gifted writer as a moral authority, humanist and representative of ethical-aesthetic imperatives and ideological principles of creativity rooted in high spiritual values, creates the best samples of journalism. Ukrainian writers Yevhen Malan'iuk, Ivan Dziuba, Lina Kostenko, Yevhen Svestiuk, Myroslav Marynovych, Oksana Pahl'ovska and several others provide briliant examples of such publicistic creativity. The values and 'diseases' of society outlined in journalistic discourses shape the appropriate symbols and codes which, on an emotional level, warn against 
repetition of past mistakes, are regulators of social behaviour and highlight the ethical dimensions of history. According to Zabuzhko the immensity of history always 'exceeds the man-made horizons of his/her understanding'. In her belief, authors should expand these horizons, accentuating that "despite all the dissociation of our cultural consciousness (...), we live in a reality of undisguised, potentially explosive history" [Zabuzhko,2007].

Permanent appeals to the historical memory of society in Ukrainian publicism may be explained by L. Nahorna's supposition that memory is a phenomenon which "serves equally as a measure and a standard of civility and morality, a foundation of identity and a source of numerous spiritual traumas" [Nahorna, 2012].

Literary-artistic and socio-political periodicals constitute a valuable source for the study of historical world changing landmarks, the re-evaluation of facts and events, as well as the exposure of both the 'whitewashed pages' and «black pages» of history which have been pivotal in reformulating and deconstructing the historical consciousness of Soviet and post-Soviet society. They have stimulated professional opinions of historians, sociologists and philosophers; promoted the adoption of new approaches, perspectives on history, events and ideas concerning the character of historical-philosophical understanding of the past and synthesised the conceptual ideas of further social and cultural development of society.

Historical socio-political current affairs periodicals became a factor influencing historiographical context in general, upgrading the standard view of analytical information and scientific language thus enabling further professional critical dialogue. Publicism itself, on the basis of theoretical and methodological achievements of European humanitarian knowledge, has syllogized the concept of 'historical memory', making the first attempts at exploring the genesis of this phenomenon and evolved approaches to understanding historical memory and its specificity in post-Soviet society.

The main trends of comprehending problems of historical memory in recurrent publications mostly depend on the position of the Editor in Chief and editorial policy. Editorial policy pursued by the Chief Editor is self-evident by the material selected for publication, by the editorial board, and also in the articles written by occasional authors. The authors decipher the search mechanisms of alternative visions of the past from various sources and in different contexts - from the level of symbolic power, political rhetoric, the mobilization of the national myth, the role of art and literature in constructing images of heroes and martyrs of the nation, common grievances, the family version of memory, and so forth.

Research suggests that original indicators in the study of publicist content, conceptual reading of publicist discourse of historical memory, understanding the reasons for actualizing certain historical events, figures and subjects of researched journals have become resources (of historical memory) which are utilised as the argumentative basis of journalistic treatise in order to maximize the impact on the reader.

In order to comprehend the concept and essence of resources of historical memory the definition of 'resource' should be provided firs of all. Its etymological content suggests reproducibility, direction, development and purposefulness. Modern terminological dictionaries succinctly define the term "resource" (Lat. resurgere - to renew, to recover) as vital to human activity, tools, supplies, sources and prerequisites.

We proposed the definition and understanding of the term 'resources of historical memory' as - "the potential which has been accumulated in a matrix of historical memory and which, in the event of necessity, becomes enabled within its carriers in order to process, understand and interpret reality". From this broad definition a number of categories of resources of historical memory have emerged: informational; cognitive; mythological; political-ideological; organizational-management; didactic; inter- 
pretative; economic; investment; cultural; spiritual-religious; emotional; conflict/reconciliation; mobilizational/motivational; modernization; military; imperialistic; identity/ self-identity.

The allocation of resources of historical memory is conditional, inasmuch as they are closely interconnected and customarily applied concurrently. But, depending upon the purpose and intended influence on the audience they are used in varying intensity. Thus, various categories of resources have been identified as follows:

- Informational resource - the information, insight and knowledge of the past which is presenting everyday circulation. The mechanisms, methods, principles of relaying historical memory and the symbolic representation of heritage are identical for the broadcast of any information in two dimensions - horizontal (between generations) and vertical (at the level of interpersonal communication).

- Cognitive resource - concentrates on accumulated past knowledge, the use of the past in the informative process and identification practices. Publicists consider past-history in the context of their own individual experience and unique knowledge. History provides vivid illustrative material, a consequence of which is the implantation of ideas, patterns and determination of the past as the cause of everything that takes place in the present and that which determines the future.

- Mythological resource is the potential to romanticise and metaphorically model the past, creating an artistic portrayal of historic events. Most predominant in journalistic speeches are the themes: fame; victory; lands soaked with blood; heroism and sacrifice of soldiers (heroic-military myths) in various historical eras that are permanently present as a motive for the statement 'we will never forget!'; the tendency to individualize historical fate, the role of the State and society in the world, the sacrifices of its people and the endurance of their character.

- Political-ideological resource - is the most important instrument in legitimizing national statehood. Insofar as the state structures its political space, it validates resolute political memory and upholds the official status of specific versions of the past as a means of affirming values in citizens' consciousness, which it perceives as significant to itself.

- Organisational-management resource - is directly linked with the politics of memory and may be perceived as its official institutionalisation. This is the coverage of issues of organisation and coordination of the system of institutes of national memory (creation of 'black' and 'white' 'memory books'), archives (the with-holding or release of supressed documents), museums (the organisation of expositions), libraries, galleries, etc.

- Didactic, or the resource of 'lessons of history' - is closely correlated with the two previous. This often takes the form of a hyperbolised state of narcissism, self-indulgence in the past which prevents the ability to see future perspective. Publicists turn to the moralistic functions of history, when the 'lessons of history' take the form of positive experience in the construction of the State, a reminder of 'golden times' or as a warning against repetition of past mistakes.

- Interpretative resource - interprets and fills in the symbolic semantic field, by providing alternative interpretations of the past on the basis of social consensus. The re-interpretation of the past and past reflections centred on humanism, and human-centricity, in the context of pan-European symbolic cultural assets. The central subject of thought appears not to be focussed on the past in general but in altering the value of specific events, historical figures or ideas.

- Economic resource - the potential to receive returns and profits from a cultural-historical heritage (in terms of the Mass Media - alternative views of past events; sensa- 
tionalism and scandal to protect ratings and sales).

- Investment resource - closely associated with economic resources; attracting investors encourages growth of the tourism industry and infrastructure, restoration of architectural monuments, renovation of memorials, statues and so forth.

- Cultural resource - an extensive system of concepts, regulations, customs, ideals and aesthetic values of society. Perceptions of the past and various manifestations of historical memory, its reflection in public discourse depend on the socio-cultural needs of society. Cultural values lay the foundations for a spiritually oriented social life, impart meaning to the life of the individual and stimulate a sense of dignity and self-realization.

- Spiritual-religious resource - is inseparable from the cultural, moral and spiritual matrix of society, the core of which is God, Faith and Truth as absolute values. The activisation of spiritual and religious resources of historical memory reveals itself in the appealing to religious traditions, cultural and artistic heritage. These may effectively confront challenges to world globalisation and prevent the loss of identity.

- Emotional resource - multi-layered resource, which includes a wide range of emotional experiences: superlative-positive (pride, joy, etc.), negative (fear, pain, moral conflicts), and particularly experience of existential discomfort induced by victimisation of historical fate (problems of identity, the sense of collapse and the difficulty of understanding the meaning of life, an inability to correct losses). Confessional publicism appeals to the sense of social cleansing, renewal, rebirth, facilitation (public catharsis). Through the deconstruction of duplicated social phobias historical, literary and scientific publicism adapts the European historical experience of reliving trauma and reconciliation with the past.

- Conflict/reconciliation resource - is based on 'hot' and 'cold' historical memories, with the help of which maximum tension and confrontation in society may be achieved. It may be used to appease social passions and restore the balance of peace or smooth the path to reconciliation. The resource of reconciliation is fundamental in times of social conflict as the main factor in stabilizing volatile situations. It accentuates the need for tolerant interpretation of the plurality of images of the past and the focus on different views which have equal rights to exist. In these cases, the emphasis is on the fundamental position to preserve the autonomy of learning as an important condition for society to have the ability to reconcile with its past.

- Mobilizational/motivational resource - the potential for self-organisation, the concentration of intellectual, moral, physical and material powers of society in times of particular threat.

- Modernization - appeal to the memory of reforms as historical phases of development.

- Military - the memories of military victories, glorified myths of invincible armies, shrines to heroes of war, heroism and selfsacrifice.

- Imperial - the memory of the imperial experience: the emergence of the empire, its growth in strength, its expansion, the memories of an era of prosperity and supremacy, the relationship between the metropolis and its colonies, the exploitation of resources of captured territories, reasons for the destruction of the empire.

- Identity/Self-identity - identification and self-realisation itself in accordance with moral and ethical coordinates, the symbolic equity of representation, concepts of our 'perfect selves', interpretation of real or imaginary historical experiences on the basis of which common and collective values, acceptable behavioural norms and so forth, are modelled. 
a specific interpretative model of the past in the public consciousness, arguing a retrospective or prospective vision of philosophical and semantically dominant ideology, of which they are representatives and carriers. Historical 'narrative', which reminds or, conversely ignores, directly reflects the spiritual-cultural and socio-political processes in society and depends upon the summons of the time. Consequently the study of the specifics, the use and intensification of these or other resources of historical memory enable the analysis of: fluctuations in world landmarks and moods; the peculiar dynamics of the rethinking and re-interpretation of facts, events, personalities and ideas of the past.

An alternative perspective of the historical progression of society embodies a display of intellectual and cognitive freedom, the prerequisite for which is a high level of responsibility and journalistic optimism.

Of extreme importance in subsequent confrontations is the ethical dimension in the application of historical memory resources. The prime responsibility lies in the words used and a pronounced understanding of their consequences. A concentrated injection of negative emotions in societies,extreme change in the spiritual climate of communities, assaying national pride, collective recollection of insults and injuries in the historical continuum, contributed to the commencement of two world wars in the twentieth century. Today, when the world is on the threshold of the third, the imperative of moral authorities, intellectuals and opinion-making publicists whose work affects the socio-political process, is to protect the fundamental principles of democracy. Alternative ways of thinking, diversity as a social value and contrasting models as representations of a prism of disclosure of subjective historical process, should not be used to deepen social confrontations, increase the degree of social illusions or for the purposes of political manipulation.

The dilemma arises when considering the extent to which positive journalism can influence deeply embedded social values which have been formulated as a consequence of centuries old historical memory based on generations of experiences (actual or perceived) as victims of tragedy, subjugation or other negative ordeals. From a moral standpoint one should consider the potential repercussions of ameliorating historical memory in order to influence future events.

Notwithstanding, involved historical memory resources combined with positive historical experience lay the foundations for spiritually oriented social coexistence, tragic historical experience performing a regulatory function, to form the symbols and codes that warn against repeating the mistakes of the past.

Thus it may be perceived that the role of the media in general and journalism in particular are primary as search tools for social consensus and reconciliation and also embrace responsibility for the future, interpretations of the past becoming directly incumbent on a commitment to contemporaries and future generations. The purpose - to create and develop or to destroy.

\section{References}

ADORNO T. W. (2005), The Meaning of Working Through the Past. [in:] NZ, Issue No2.

ERLL A. (2008), Cultural Memory Studies: An Introduction. [in:] Media and Cultural Memory. Berlin/New York, NY: de Gruyter.

HALBWACHS M. (2005), Historical Memory and Collective Memory. [in:] NZ. Issue 2-3.

Hutton P. (2003), History as the Art of Memory. St. Petersburg, Vladimir Dal.

LYLYO T. (2011), De-historification of Consciousness as a Precondition for the Effectiveness of Manipulative Ideology in Modern Journalism [in:] Visnyk Lviv Univ, Series Journalism. Issue 35.

LOS J. (2004), Journalism Facing a New Challenge [in:] Visnyk Lviv Univ, Series Journalism. Issue 25. 
MOROZOV S.M., SHKARAPUTA L.M. (2000), Dictionary of Foreign Words. Kiev, Naukova Dumka, SKOPNENKO O.I. \& TSYMBALIUK T.V (2006), A Modern Dictionary of Foreign Words, Kiev, Dovira.

MALICKI K. (2012, Memory of the Past Generations of Transformation. Warsaw, Educational Publishers Scholar.

NAHORNA L. (2012), Historical Memory: theory, discourse, reflection, Kyjiv, National Academy of Science of Ukraine.

NORA P., OZOUF, M., PYUIMEZH G, DE. \& WINOCK M. (1999), The Problem of Memory Locations, [in:] France Memory. St Petersburg University Press.

ZABUZHKO O. (2007), Ukrayinka in the Conflict of Mythologies. Kyjiv, Fakt.

ZELIZER B. (2014), Journalism and Memory. K.Tenenboim-Weinblatt (Ed.), Palgrave Macmillan Memory Studies. 